\title{
High Efficient Photocatalytic Degradation of Methyl Orange Dye in an Aqueous Solution by $\mathrm{CoFe}_{2} \mathrm{O}_{4}-\mathrm{SiO}_{2}-\mathrm{TiO}_{2}$ Magnetic Catalyst
}

\author{
Poedji Loekitowati Hariani ${ }^{*}$, Muhammad Said ${ }^{1}$, Salni $^{2}$, Nabila Aprianti ${ }^{3}$, \\ Yohanna Asina Lasma Rohana Naibaho' \\ 1 Department of Chemistry, Faculty of Mathematics and Natural Sciences, Sriwijaya University, Jalan \\ Palembang-Prabumulih, Indralaya, Ogan Ilir, Indonesia \\ 2 Department of Biology, Faculty of Mathematics and Natural Sciences, Sriwijaya University, Jalan \\ Palembang-Prabumulih, Indralaya, Ogan Ilir, Indonesia \\ 3 Doctoral Program of Environmental Science, Graduate School, Sriwijaya University, Jalan Padang Selasa 524 \\ Bukit Besar, Palembang 30139, South Sumatra, Indonesia \\ * Corresponding author's email: puji_lukitowati@mipa.unsri.ac.id
}

\begin{abstract}
This study successfully synthesized a core-shell-shell in the form of $\mathrm{CoFe}_{2} \mathrm{O}_{4}-\mathrm{SiO}_{2}-\mathrm{TiO}_{2}$ catalyst magnetic and recyclable. The catalyst was employed for the photocatalytic degradation of methyl orange (MO) dye. Subsequently, the catalyst was subjected to XRD, FTIR, SEM-EDS, VSM, as well as UV-DRS characterizations. The photocatalytic degradation was studied as a function of the solution $\mathrm{pH}, \mathrm{MO}$ concentration, and irradiation time, while the kinetics of photocatalytic degradation and the catalyst reusability were also evaluated. On the basis of the XRD, FTIR, and SEM-EDS characterizations, the $\mathrm{CoFe}_{2} \mathrm{O}_{4}$ coating was successfully carried out using $\mathrm{SiO}_{2}$ and $\mathrm{TiO}_{2}$. $\mathrm{CoFe}_{2} \mathrm{O}_{4}-\mathrm{SiO}_{2}-\mathrm{TiO}_{2}$ was discovered to possess magnetic properties with a saturation magnetization of 17.59 $\mathrm{emu} / \mathrm{g}$ and a bandgap value of $2.4 \mathrm{eV}$. The photocatalytic degradation of MO followed the Langmuir-Hishelwood model. The optimum degradation was obtained at the $\mathrm{MO}$ concentration of $25 \mathrm{mg} / \mathrm{L}$, solution $\mathrm{pH}$ of 4 , catalyst dose of $0.05 \mathrm{~g} / \mathrm{L}$, irradiation time of 160 minutes, MO removal efficiency achieved $93.46 \%$. The regeneration study showed $\mathrm{CoFe}_{2} \mathrm{O}_{4}-\mathrm{SiO}_{2}-\mathrm{TiO}_{2}$ after 5 cycles were able to catalyze the photocatalytic degradation with an $\mathrm{MO}$ removal efficiency of $89.96 \%$.
\end{abstract}

Keywords: $\mathrm{CoFe}_{2} \mathrm{O}_{4}-\mathrm{SiO}_{2}-\mathrm{TiO}_{2}$, magnetic, degradation, photocatalytic, and methyl orange.

\section{INTRODUCTION}

The continuous discharge of industrial liquid waste containing toxic compounds into water bodies tends to cause environmental pollution and presents several health risks [Ojemaye et al., 2015]. The previous studies by Chan et al. [2008] and Trabelsi et al. [2016] described dyes as toxic compounds produced by several industries, including the textile, pharmaceutical, chemical, paper, foodstuff, soap, cosmetic, and leather industries, where over $50 \%$ of the dyes used are azo-based. According to Koohestani et al. [2016], azo dyes are the compounds with an azo bond in the form of $-\mathrm{N}=\mathrm{N}-$. Over $15 \%$ of the dyes are discharged as liquid waste during the dyeing and coloring process [Nair et al., 2014; Ahmad et al., 2014]. Azo dyes and their intermediates, for instance aromatic amines, are highly stable, toxic, carcinogenic, mutagenic, and not easily degraded [Konstantinou and Albanis, 2004; Alghamdi et al., 2019]. A report by Huang et al. [2008] showed that dyes block the penetration of light into the water, consequently lowering the photosynthetic efficiency and impeding the growth of aquatic organisms. These dyes also cause aesthetic changes which are harmful to the environment. Methyl orange (MO) is an azo dye with the molecular formula $\mathrm{C}_{14} \mathrm{H}_{14} \mathrm{~N}$ ${ }_{3} \mathrm{SO}_{3} \mathrm{Na}$ and is classified as an anionic dye with 
a sulfonic group. In addition to being used as an industrial coloring agent, $\mathrm{MO}$ is also used as a $\mathrm{pH}$ indicator in the laboratory, with a $\mathrm{pH}$ indicator range of 3.1 to 4.4 [Alghamdi et al., 2019].

Recently, advanced oxidative processes (AOPs) were discovered to be the most effective method for degrading organic matter from water and wastewater [Suzuki et al., 2015; Mrotek et al., 2020]. These processes are based on the formation of highly reactive radicals, including hydroxyl groups, which oxidize and convert organic compounds into harmless products, for instance, $\mathrm{CO}_{2}$ and $\mathrm{H}_{2} \mathrm{O}$ [Ge et al. 2019; Takdastan et al., 2018]. Heterogeneous photocatalysis using semi-conductors is an effective technique for the degradation of toxic organic compounds. In wastewater treatment, $\mathrm{TiO}_{2}$ in various forms is a widely used photocatalyst due to the its ease and low cost of production, high photoactivity, nontoxicity, as well as good electrical and thermal conductivity [Shojaie et al., 2018; Stefan et al., 2016, Subramonian et al., 2017].

However, $\mathrm{TiO}_{2}$ is suspended in a solution, which makes it difficult to separate and energyconsuming processes [Lee et al., 2001; Jorfi et al., 2017], electron-hole recombination of the photo-generated charge carriers [Pastravanu et al., 2014], as well as a wide bandgap (about $3.2 \mathrm{eV}$ ) [Djellabi et al., 2019]. Therefore, $\mathrm{TiO}_{2}$ is only suitable for use under UV light to generate electron-hole pairs. Alternatively, magnetic photocatalysts in which semiconductor nanoparticles are deposited on the ferrite surface $\left(\mathrm{Fe}_{3} \mathrm{O}_{4}\right.$, $\mathrm{Fe}_{2} \mathrm{O}_{4}, \mathrm{CoFe}_{2} \mathrm{O}_{4}, \mathrm{ZnFe}_{2} \mathrm{O}_{4}$ ), has been used to facilitate the separation of the photocatalyst from the solution, using an external magnet [Jurek et al., 2017, Mishra et al., 2019]. The coating of $\mathrm{Fe}_{3} \mathrm{O}_{4}$ as the core, with $\mathrm{TiO}_{2}$, reduces the bandgap of $\mathrm{TiO}_{2}$, making the compound suitable for the photocatalytic visible region while increasing the speed and efficiency of the separation process [Mercyrani et al., 2017]. However, direct contact between ferrite compounds and $\mathrm{TiO}_{2}$ causes $\mathrm{TiO}_{2}$ to enter the core oxidizing iron, and consequently, the ferrous ions dissolve into solution (photo-dissolution) [Gebrezgiabher et al., 2019; Wysocka et al., 2018]. According to Rashid et al. [2015] and Jurek et al. [2017], the formation of a layer on the magnetic core helps to prevent degradation, photo-dissolution, and adverse effects of the magnetic core on $\mathrm{TiO}_{2}$. Silica protects the magnetic core, prevents the transmission of electron holes from the photocatalyst layer to the magnetic part, and is, therefore, often used as an intermediary [Awazu et al., 2008; Cheng et al., 2012].

In this study, a core-shell-shell in the form of $\mathrm{CoFe}_{2} \mathrm{O}_{4} / \mathrm{SiO}_{2} / \mathrm{TiO}_{2}$ was prepared as a photocatalyst for the degradation of $\mathrm{MO} . \mathrm{CoFe}_{2} \mathrm{O}_{4}$ was selected as the core due to its high thermal and chemical stability, low toxicity, high coercivity, as well as moderate magnetization [Rajput and Kaur, 2014; El-Shobaky et al., 2010]. Subsequently, the photocatalytic efficiency of the degradation, including the effect of solution $\mathrm{pH}$, irradiation time, as well as catalyst dose, were investigated, and the reusability of catalysts was evaluated.

\section{MATERIAL AND METHODS}

\section{Materials}

The study involved the use of cobalt chloride hexahydrate $\left(\mathrm{CoCl}_{2} \cdot 6 \mathrm{H}_{2} \mathrm{O}\right)$, Iron(III) chloride hexahydrate $\left(\mathrm{FeCl}_{3} \cdot 6 \mathrm{H}_{2} \mathrm{O}\right)$, Trisodium citrate dihydrate $\left(\mathrm{C}_{6} \mathrm{H}_{5} \mathrm{Na}_{3} \mathrm{O}_{7} \cdot 2 \mathrm{H}_{2} \mathrm{O}\right)$, ethanol $\left(\mathrm{C}_{2} \mathrm{O}_{5} \mathrm{OH}\right)$, Sodium hydroxide $(\mathrm{NaOH})$, Hidrochlorid acid $(\mathrm{HCl})$, Tetraethyl orthosilicate $\left(\mathrm{Si}\left(\mathrm{OC}_{2} \mathrm{H}_{5}\right)_{4}\right.$, Ammonium hidroxide $\left(\mathrm{NH}_{4} \mathrm{OH}\right)$, Methyl orange $\left(\mathrm{C}_{14} \mathrm{H}_{14} \mathrm{~N}_{3} \mathrm{SO}_{3} \mathrm{Na}\right)$, Titanium (IV) butoxide $\left(\mathrm{Ti}\left(\mathrm{OCH}_{2} \mathrm{CH}_{2} \mathrm{CH}_{2} \mathrm{CH}_{3}\right)_{4}\right.$, Ethylene glycol $\left(\mathrm{CH}_{2} \mathrm{OH}\right)_{2}$, Sodium nitrate $\left(\mathrm{NaNO}_{3}\right)$, Titanium dioxide $\left(\mathrm{TiO}_{2}\right)$ from Merck, Germany.

\section{$\mathrm{CoFe}_{2} \mathrm{O}_{4}$ preparation}

$\mathrm{CoFe}_{2} \mathrm{O}_{4}$ was synthesized using the coprecipitation method. For this process, $9.517 \mathrm{~g}$ of $\mathrm{CoCl}_{2} \cdot 6 \mathrm{H}_{2} \mathrm{O}$ and $21.623 \mathrm{~g}$ of $\mathrm{FeCl}_{3} \cdot 6 \mathrm{H}_{2} \mathrm{O}$ were dissolved in $100 \mathrm{~mL}$ of distilled water. Subsequently, $2 \mathrm{M} \mathrm{NaOH}$ was added to the solution in drops, while nitrogen gas was passed across until a $\mathrm{pH}$ of 10 was obtained. The precipitate obtained was then collected by magnetic separation, washed several times with distilled water until the $\mathrm{pH}$ was neutral, and oven-dried at $110^{\circ} \mathrm{C}$ for 1 hour. This was followed by subjecting the $\mathrm{CoFe}_{2} \mathrm{O}_{4}$ obtained to further calcination at $800{ }^{\circ} \mathrm{C}$ for 2 hours.

\section{$\mathrm{CoFe}_{2} \mathrm{O}_{4}-\mathrm{SiO}_{2}$ preparation}

The synthesis of $\mathrm{CoFe}_{2} \mathrm{O}_{4}-\mathrm{SiO}_{2}$ was carried out using the sol-gel method. For this process, $0.8 \mathrm{~g}$ of $\mathrm{CoFe}_{2} \mathrm{O}_{4}$ and $0.8 \mathrm{~g}$ of Trisodium citrate dihydrate were dissolved in $20 \mathrm{~mL}$ of ethanol and 
$8 \mathrm{~mL}$ of distilled water. The mixture was then homogenized by sonification for 10 minutes, and $4 \mathrm{~mL}$ of ammonium hydroxide, as well as $3.2 \mathrm{~mL}$ of TEOS, were added to the solution, and sonification was continued for 3 hours at $40{ }^{\circ} \mathrm{C}$ to form a silica layer around $\mathrm{CoFe}_{2} \mathrm{O}_{4}$. Subsequently, the precipitate obtained was separated by centrifugation, washed severally with ethanol, and dried using rotary evaporation.

\section{$\mathrm{CoFe}_{2} \mathrm{O}_{4}-\mathrm{SiO}_{2}-\mathrm{TiO}_{2}$ preparation}

The $\mathrm{CoFe}_{2} \mathrm{O}_{4}-\mathrm{SiO}_{2}-\mathrm{TiO}_{2}$ composites were prepared using the method reported by Habila et al. [2015], with some modifications. For this process, $2 \mathrm{~g}$ of $\mathrm{CoFe}_{2} \mathrm{O}_{4}-\mathrm{SiO}_{2}$ was suspended in a mixture of $24 \mathrm{~mL}$ ethanol, $30 \mathrm{~mL}$ distilled water, and $800 \mathrm{~L}$ ammonium hydroxide (28\%), using sonification, for 30 minutes. Subsequently, $20 \mathrm{~mL}$ of ethylene glycol and $2 \mathrm{~mL}$ of TBT solution were slowly added and the mixture was homogenized using a magnetic stirrer at $45{ }^{\circ} \mathrm{C}$, for 24 hours. The $\mathrm{CoFe}_{2} \mathrm{O}_{4}-\mathrm{SiO}_{2}-\mathrm{TiO}_{2}$ obtained was washed with distilled water, as well as ethanol, then ovendried at $110{ }^{\circ} \mathrm{C}$ for 1 hour and calcined at $450{ }^{\circ} \mathrm{C}$ for 3 hours.

\section{Characterization}

The crystal structure and phase of catalyst were analyzed using X-Ray Diffraction (XRD PANalytical), while the functional groups were identified using Fourier Transform Infra-Red (FTIR Prestige 21 Shimadzu). In addition, the morphology and elemental composition were analyzed using a Scanning Electron MicroscopeEnergy Dispersive Spectrometer (SEM-EDS JOEL JSM 6510 LA). The magnetic moment was determined using a Vibrating Sample Magnetometer (VSM Oxford Type 1.2 T). At the same time, the wavelength and band gap were analyzed using Diffuse Reflectance Ultra VioletVisible Spectroscopy (UV-Vis DRS Pharmaspec UV-1700). The radiation source for photocatalytic degradation was UV light (12 W Phillips) and the MO absorbance was measured using a UV-Vis Spectrophotometer (Type Orion Aquamate 8000). Mineralization degree was measurement by Total Organic Carbon (TOC Teledyne Tekmar). Determination of pHpzc was carried out following a modification of the technique reported by Bezahdi et al. [2020] using $\mathrm{NaNO}_{3}$ solution as an electrolyte.

\section{Photocatalytic degradation}

In this experiment, $50 \mathrm{~mL}$ of $\mathrm{MO}$ was mixed with $\mathrm{CoFe}_{2} \mathrm{O}_{4}-\mathrm{SiO}_{2}-\mathrm{TiO}_{2}$ at a dose of $0.05 \mathrm{~g} / \mathrm{L}$ in separate quartz pipes, with the MO concentrations of 25, 50, 75, and $100 \mathrm{mg} / \mathrm{L}$. Using UV light as the irradiation source, the mixture was placed in a photoreactor with a vessel distance of $30 \mathrm{~cm}$ from the light source. Furthermore, the effects of the $\mathrm{pH}$ and irradiation time were studied by varying the $\mathrm{pH}$ in the range of 2 to 7 , as well as the irradiation time between 0 to 200 minutes. Subsequently, the MO removal (\%) was calculated using the following formula (Eq. 1).

$$
\text { MO Removal }(\%)=\frac{C_{o}-C_{t}}{C_{o}}
$$

where: $C_{o}$ and $C_{t}$ are the initial and final concentrations of $\mathrm{MO}(\mathrm{mg} / \mathrm{L})$.

The reusability of the catalyst was also investigated using the same method, under the optimum conditions for photocatalytic degradation. For this evaluation, the $\mathrm{CoFe}_{2} \mathrm{O}_{4}-\mathrm{SiO}_{2}-\mathrm{TiO}_{2}$ was separated using a permanent magnet after the photocatalytic degradation, then washed with ethanol and distilled water, dried in an oven for 60 minutes at $80^{\circ} \mathrm{C}$, and reused for photocatalytic degradation [Ajabshir and Niasari, 2019]. This experiment was repeated 5 times, and the catalyst efficiency was measured after each cycle.

\section{RESULT AND DISCUSSION}

\section{Properties of the materials}

Figure 1 shows the XRD spectra of the synthesized $\mathrm{CoFe}_{2} \mathrm{O}_{4}, \mathrm{CoFe}_{2} \mathrm{O}_{4}-\mathrm{SiO}_{2}$, and $\mathrm{CoFe}_{2} \mathrm{O}_{4}-$ $\mathrm{SiO}_{2}-\mathrm{TiO}_{2}$. On the basis of the diagram, the $2 \theta$ angle of $\mathrm{CoFe}_{2} \mathrm{O}_{4}$ was observed at $30.31^{\circ}(220)$, $35.57^{\circ}(311), 43.21^{\circ}(400), 53.61^{\circ}(422), 57.23^{\circ}$ (511), and $62.81^{\circ}(440)$. This peak is a characteristic of the cubic spinel structure phase following the standard $\mathrm{CoFe}_{2} \mathrm{O}_{4}$ spectra (JCPDS card No. 78-1744). Meanwhile, $\mathrm{CoFe}_{2} \mathrm{O}_{4}-\mathrm{SiO}_{2}$ was discovered to possess the same diffraction angle as $\mathrm{CoFe}_{2} \mathrm{O}_{4}$, but with lower peak intensity. Furthermore, the crystalline properties of $\mathrm{CoFe}_{2} \mathrm{O}_{4}$ were maintained after coating with $\mathrm{SiO}_{2}$. The peak for $\mathrm{SiO}_{2}$ at $2 \theta=15-25$ was not observed in the XRD spectra of $\mathrm{CoFe}_{2} \mathrm{O}_{4}-\mathrm{SiO}_{2}$ and $\mathrm{CoFe}_{2} \mathrm{O}_{4}-\mathrm{SiO}_{2}-\mathrm{TiO}_{2}$, 


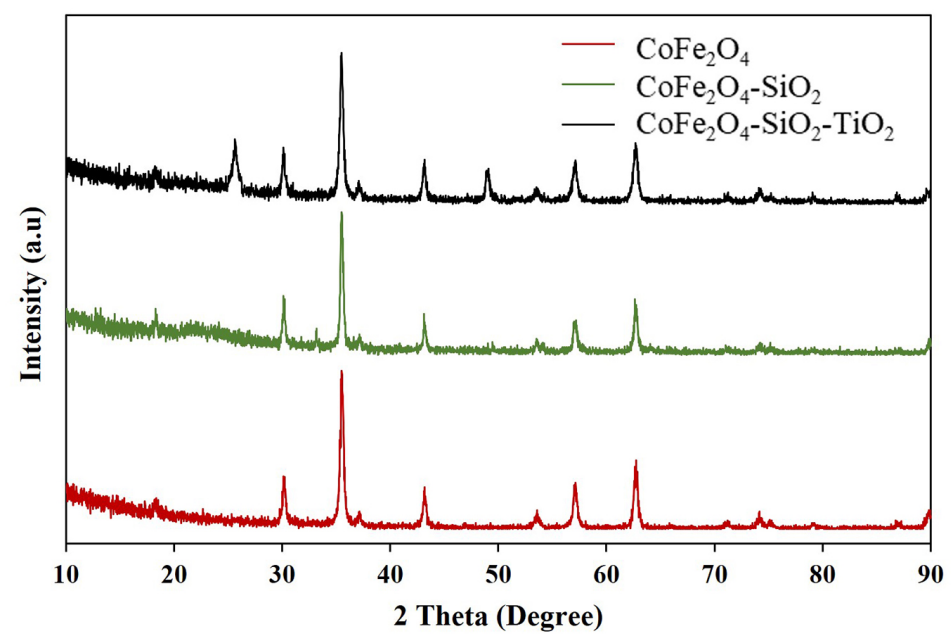

Figure 1. $\mathrm{XRD}$ spectra of (a) $\mathrm{CoFe}_{2} \mathrm{O}_{4}$ (b) $\mathrm{CoFe}_{2} \mathrm{O}_{4}-\mathrm{SiO}_{2}$ and (c) $\mathrm{CoFe}_{2} \mathrm{O}_{4}-\mathrm{SiO}_{2}-\mathrm{TiO}_{2}$

due to the amorphous nature of $\mathrm{SiO}_{2}$. Habila et al. [2020] reported a similar pattern in the synthesis of $\mathrm{Fe}_{3} \mathrm{O}_{4} / \mathrm{SiO}_{2} / \mathrm{TiO}_{2}$, where a reduction occurred in the $\mathrm{Fe}_{3} \mathrm{O}_{4}$ diffraction peak after coating with $\mathrm{SiO}_{2}$ and $\mathrm{TiO}_{2}$, due to the shielding effect of the two compounds.

The XRD spectra of $\mathrm{CoFe}_{2} \mathrm{O}_{4}-\mathrm{SiO}_{2}-\mathrm{TiO}_{2}$ shows the presence of a $2 \theta$ angle, which is characteristic of $\mathrm{TiO} 2$ at 25.63 (101), 37.25 (004), 48.87 (200), and 62.91 (204), based on the anatase phase structure (JCPDS card No. 21-1272). Table 1 shows the average crystallite size of Co$\mathrm{Fe}_{2} \mathrm{O}_{4}, \mathrm{CoFe}_{2} \mathrm{O}_{4}-\mathrm{SiO}_{2}$, and $\mathrm{CoFe}_{2} \mathrm{O}_{4}-\mathrm{SiO}_{2}-\mathrm{TiO}_{2}$ calculated by the Scherrer formula. The crystallite size of $\mathrm{CoFe}_{2} \mathrm{O}_{4}$ before and after coating remained at a constant value of $\pm 33 \mathrm{~nm}$. Meanwhile, the average crystal size of $\mathrm{TiO}_{2}$ calculated at the peak of the anatase diffraction was $18.3 \mathrm{~nm}$.

Figure 2 shows the FTIR spectra of $\mathrm{CoFe}_{2} \mathrm{O}_{4}$, $\mathrm{CoFe}_{2} \mathrm{O}_{4}-\mathrm{SiO}_{2}$, and $\mathrm{CoFe}_{2} \mathrm{O}_{4}-\mathrm{SiO}_{2}-\mathrm{TiO}_{2}$. The wavenumbers observed at about $3400 \mathrm{~cm}^{-1}$ and $1630 \mathrm{~cm}^{-1}$ in all spectra are stretching vibrations of the hydroxyl functional group $(\mathrm{O}-\mathrm{H})$ originating from free water molecules on the catalyst surface [Ojemaye et al., 2017]. Meanwhile, the $\mathrm{CoFe}_{2} \mathrm{O}_{4}$ spectra in the form of sharp peaks at $576 \mathrm{~cm}^{-1}$ are the vibrations of $\mathrm{Fe}-\mathrm{O}$. The strong peak at $1093 \mathrm{~cm}^{-1}$ observed in $\mathrm{CoFe}_{2} \mathrm{O}_{4}-\mathrm{SiO}_{2}$, and

Table 1. The average crystallite size of $\mathrm{CoFe}_{2} \mathrm{O}_{4}$, $\mathrm{CoFe}_{2} \mathrm{O}_{4}-\mathrm{SiO}_{2}$ dan $\mathrm{CoFe}_{2} \mathrm{O}_{4}-\mathrm{SiO}_{2}-\mathrm{TiO}_{2}$

\begin{tabular}{|l|c|c|}
\hline \multirow{2}{*}{ Materials } & \multicolumn{2}{|c|}{ Average crystallite size (nm) } \\
\cline { 2 - 3 } & $\mathrm{CoFe}_{2} \mathrm{O}_{4}$ & $\mathrm{TiO}_{2}$ \\
\hline $\mathrm{CoFe} \mathrm{O}_{4}$ & 33.24 & - \\
\hline $\mathrm{CoFe}_{2} \mathrm{O}_{4}-\mathrm{SiO}_{2}$ & 33.40 & - \\
\hline $\mathrm{CoFe}_{2} \mathrm{O}_{4}-\mathrm{SiO}_{2}-\mathrm{TiO}_{2}$ & 33.34 & 18.24 \\
\hline
\end{tabular}

$\mathrm{CoFe}_{2} \mathrm{O}_{4}-\mathrm{SiO}_{2}-\mathrm{TiO}_{2}$, is an asymmetric vibration of Si-O-Si [Fu et al., 2019], while the wavenumber around $950 \mathrm{~cm}^{-1}$ is the vibration of the Si-O-H band [Mortazavi et al., 2017]. According to Fu et al., [2019], the presence of $\mathrm{TiO}_{2}$ in the $\mathrm{CoFe}_{2} \mathrm{O}_{4}{ }^{-}$ $\mathrm{SiO}_{2}-\mathrm{TiO}_{2}$ spectra visible at 450 to $700 \mathrm{~cm}^{-1}$, is the vibration of Ti-O-Ti and Ti-O-Si.

The SEM and EDS analyses are used to investigate the morphology and composition of the catalyst elements. Figure 3 shows the morphology of $\mathrm{CoFe}_{2} \mathrm{O}_{4}, \mathrm{CoFe}_{2} \mathrm{O}_{4}-\mathrm{SiO}_{2}$, and $\mathrm{CoFe}_{2} \mathrm{O}_{4}-$ $\mathrm{SiO}_{2}-\mathrm{TiO}_{2}$ with the same magnification. The morphology of $\mathrm{CoFe}_{2} \mathrm{O}_{4}$ appears spherical because due to the small size which tends to agglomerate and the morphology of $\mathrm{CoFe}_{2} \mathrm{O}_{4}-\mathrm{SiO}_{2}$ is similar to $\mathrm{CoFe}_{2} \mathrm{O}_{4}$ but more homogeneous. This is consistent with the XRD results which show the $\mathrm{SiO}_{2}$ coating is not observed in the spectra due to the amorphous nature of the compound. Meanwhile, a heterogeneous and rough surface is visible in the morphology of $\mathrm{CoFe}_{2} \mathrm{O}_{4}-\mathrm{SiO}_{2}-\mathrm{TiO}_{2}$ where the $\mathrm{TiO}_{2}$ aggregates appear to be round and coat the $\mathrm{CoFe}_{2} \mathrm{O}_{4}-\mathrm{SiO}_{2}$. Table 2 shows the elemental composition of $\mathrm{CoFe}_{2} \mathrm{O}_{4}, \mathrm{CoFe}_{2} \mathrm{O}_{4}-\mathrm{SiO}_{2}$, and $\mathrm{CoFe}_{2} \mathrm{O}_{4}-$ $\mathrm{SiO}_{2}-\mathrm{TiO}_{2}$ from the EDS analysis, where the presence of $\mathrm{Si}$ and $\mathrm{Ti}$ elements in $\mathrm{CoFe}_{2} \mathrm{O}_{4}-\mathrm{SiO}_{2}-\mathrm{TiO}_{2}$ indicates a successful synthesis. Furthermore, no other elements were detected as impurities.

Figure 4 shows the magnetization curves of $\mathrm{CoFe}_{2} \mathrm{O}_{4}, \mathrm{CoFe}_{2} \mathrm{O}_{4}-\mathrm{SiO}_{2}$, and $\mathrm{CoFe}_{2} \mathrm{O}_{4}-\mathrm{SiO}_{2}-$ $\mathrm{TiO}_{2}$ obtained using VSM. According to the results, the saturation magnetization of $\mathrm{CoFe}_{2} \mathrm{O}_{4}$ is $57.05 \mathrm{emu} / \mathrm{g}$, and this value is close to the saturation magnetization of $\mathrm{CoFe}_{2} \mathrm{O}_{4}$ synthesized using the combustion, coprecipitation, and precipitation methods, which are 56.7, 55.8, and 


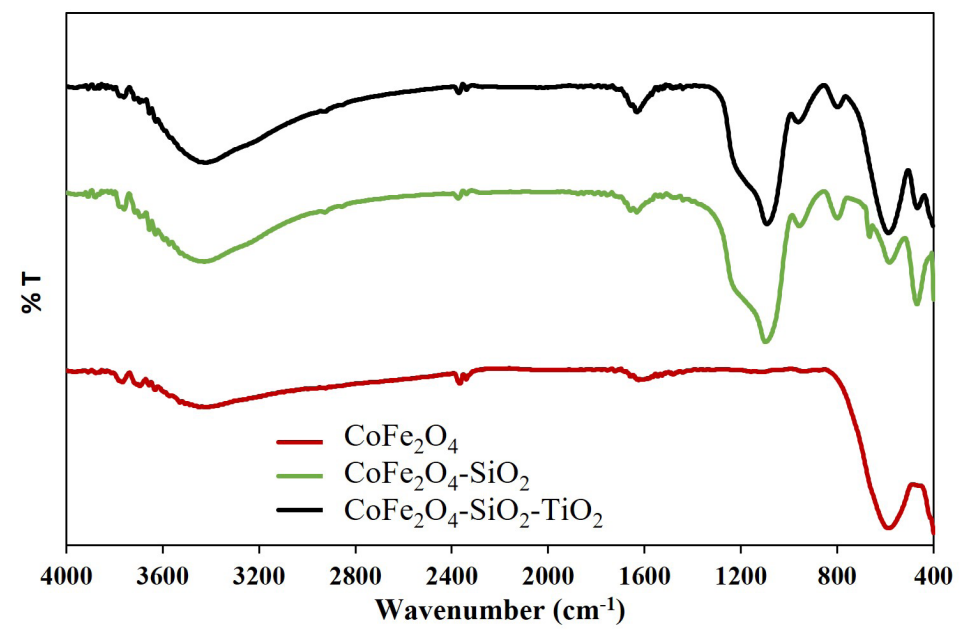

Figure 2. FTIR spectra (a) $\mathrm{CoFe}_{2} \mathrm{O}_{4}$ (b) $\mathrm{CoFe}_{2} \mathrm{O}_{4}-\mathrm{SiO}_{2}$ and (c) $\mathrm{CoFe}_{2} \mathrm{O}_{4}-\mathrm{SiO}_{2}-\mathrm{TiO}_{2}$

$47.2 \mathrm{emu} / \mathrm{g}$, respectively [Houshiar et al., 2014]. In addition, the saturation magnetization of $\mathrm{Co}$ $\mathrm{Fe}_{2} \mathrm{O}_{4}-\mathrm{SiO}_{2}$ and $\mathrm{CoFe}_{2} \mathrm{O}_{4}-\mathrm{SiO}_{2}-\mathrm{TiO}_{2}$ are 40.01 $\mathrm{emu} / \mathrm{g}$, as well as $17.59 \mathrm{emu} / \mathrm{g}$, respectively, and these values are lower, compared to the Co$\mathrm{Fe}_{2} \mathrm{O}_{4}$ counterpart. This means that coating with non-magnetic material leads to a reduction in saturation magnetization. However, $\mathrm{CoFe}_{2} \mathrm{O}_{4}^{-}$ $\mathrm{SiO}_{2}-\mathrm{TiO}_{2}$ still has possessed good magnetic properties, considering the material is quickly and easily separated from the solution after degradation, using a permanent magnet. a)

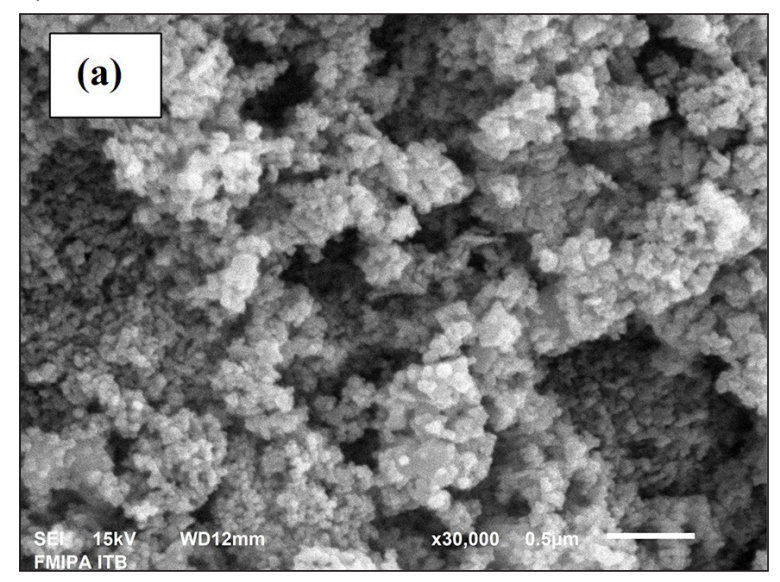

b)

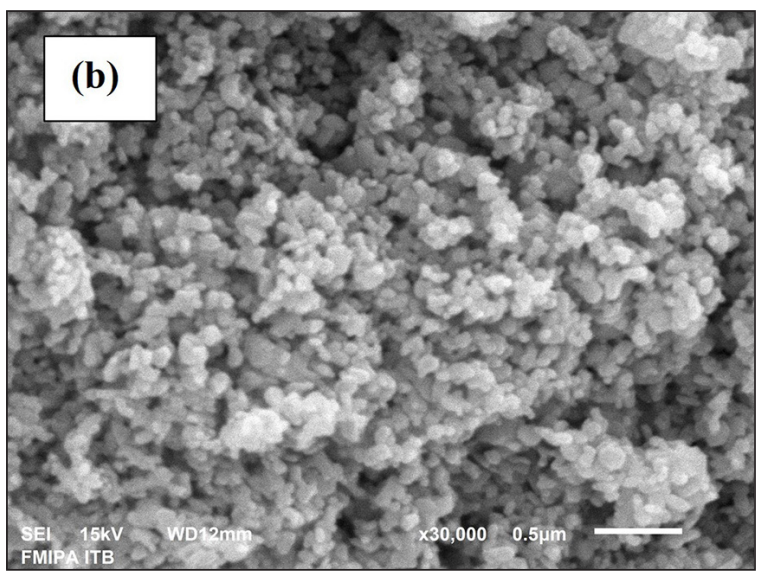

c)

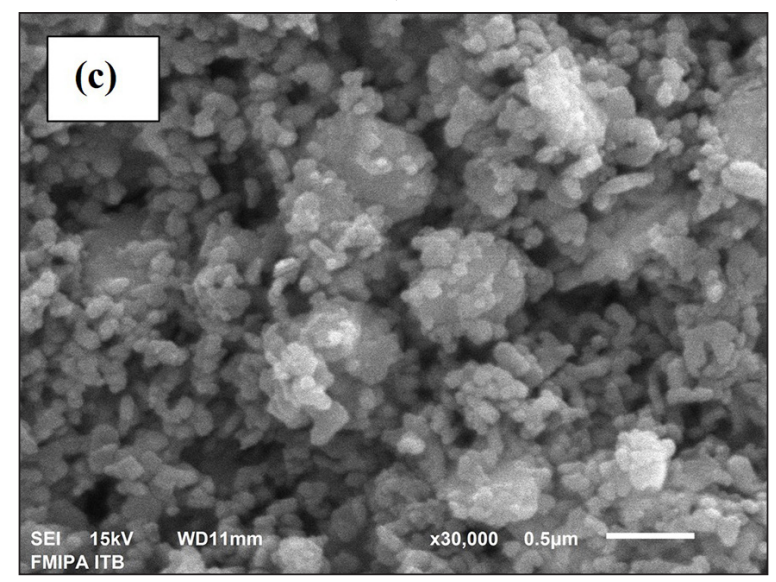

Figure 3. Morphology of (a) $\mathrm{CoFe}_{2} \mathrm{O}_{4}$ (b) $\mathrm{CoFe}_{2} \mathrm{O}_{4}-\mathrm{SiO}_{2}$ and (c) $\mathrm{CoFe}_{2} \mathrm{O}_{4}-\mathrm{SiO}_{2}-\mathrm{TiO}_{2}$ 
Table 2. Elements of $\mathrm{CoFe}_{2} \mathrm{O}_{4}, \mathrm{CoFe}_{2} \mathrm{O}_{4}-\mathrm{SiO}_{2}$ dan $\mathrm{CoFe}_{2} \mathrm{O}_{4}-\mathrm{SiO}_{2}-\mathrm{TiO}_{2}$

\begin{tabular}{|c|c|c|c|}
\hline \multirow{2}{*}{ Elements (\%) } & \multicolumn{3}{|c|}{ Materials } \\
\cline { 2 - 4 } & $\mathrm{CoFe}_{2} \mathrm{O}_{4}$ & $\mathrm{CoFe}_{2} \mathrm{O}_{4}-\mathrm{SiO}_{2}$ & $\begin{array}{c}\mathrm{CoFe}_{2} \mathrm{O}_{4}-\mathrm{SiO}_{2}- \\
\mathrm{TiO}_{2}\end{array}$ \\
\hline $\mathrm{O}$ & 19.43 & 23.27 & 26.18 \\
\hline $\mathrm{Co}$ & 27.76 & 28.77 & 23.19 \\
\hline $\mathrm{Fe}$ & 52.81 & 44.63 & 37.63 \\
\hline $\mathrm{Si}$ & - & 3.32 & 12.25 \\
\hline $\mathrm{Ti}$ & - & - & 0.75 \\
\hline
\end{tabular}

Furthermore, Figures $5 \mathrm{a}$ and $\mathrm{b}$ show the UVDRS spectra of $\mathrm{CoFe}_{2} \mathrm{O}_{4}-\mathrm{SiO}_{2}-\mathrm{TiO}_{2}$ and pure (commercial) $\mathrm{TiO}_{2}$, which provide the information about the wavelength at which the catalyst absorbs energy. The results showed $\mathrm{TiO}_{2}$ absorbs in the ultraviolet region with a maximum absorbance of about $345 \mathrm{~nm}$, and this activity is due to the fairly large bandgap. Meanwhile, $\mathrm{CoFe}_{2} \mathrm{O}_{4}-$ $\mathrm{SiO}_{2}-\mathrm{TiO}_{2}$ not only absorbs in the ultra-visible region but also in the visible region, at wavelengths of 341 and $425 \mathrm{~nm}$, respectively. The bandgap value was obtained by plotting $(\alpha h v)^{2}$ against $\mathrm{h} v$ (Figure $5 \mathrm{~b}$ ). $\mathrm{A} \mathrm{TiO}_{2}$ band gap of $3.2 \mathrm{eV}$ was obtained, and coating $\mathrm{CoFe}_{2} \mathrm{O}_{4}$ with $\mathrm{SiO}_{2}$ and $\mathrm{TiO}_{2}$ reduces the bandgap. Therefore, $\mathrm{CoFe}_{2} \mathrm{O}_{4}-$ $\mathrm{SiO}_{2}-\mathrm{TiO}_{2}$ has a bandgap of $2.4 \mathrm{eV}$. According to Sonu et al., (2019), $\mathrm{CoFe}_{2} \mathrm{O}_{4}$ has a fairly small bandgap $(\sim 1.76 \mathrm{eV})$.

\section{Photocatalytic properties}

In photocatalytic degradation, the solution $\mathrm{pH}$ influences the charge of the catalyst surface. The solution $\mathrm{pH}$ is an important parameter.
A report by Behzadi et al. [2020] showed the optimum $\mathrm{pH}$ depends on the type of pollutant and the pHpzc, which shows the $\mathrm{pH}$ on the material surface in total is zero or the catalyst surface is neutrally charged [Amulya et al., 2020]. The pHpzc value must be investigated to determine the appropriate $\mathrm{pH}$ for an effective photocatalytic degradation process. The pHpzc of $\mathrm{CoFe}_{2} \mathrm{O}_{4}{ }^{-}$ $\mathrm{SiO}_{2}-\mathrm{TiO}_{2}$ is 5.2 .

Figure 7 shows the effect of solution $\mathrm{pH}$ on the removal of $\mathrm{MO}$, which has a $\mathrm{pH}$ range of 3.1-4.4 with a $\mathrm{pKa}$ of 3.7. At a solution $\mathrm{pH}<\mathrm{pHpzc}$, $\mathrm{CoFe}_{2} \mathrm{O}_{4}-\mathrm{SiO}_{2}-\mathrm{TiO}_{2}$ is positively charged, while $\mathrm{MO}$ is an anionic dye, and consequently, the attraction is more effective. MO removal increases at $\mathrm{pH} 2$ to 4 and subsequently decreases at $\mathrm{pH} 5$. Meanwhile, at a solution $\mathrm{pH}>\mathrm{pHpzc}$, there is a repulsion of electrostatic charges between the anionic dye and the negatively charged $\mathrm{CoFe}_{2} \mathrm{O}_{4}$ $\mathrm{SiO}_{2}-\mathrm{TiO}_{2}$. The highest MO removal was obtained at $\mathrm{pH} 4$ with variations in the initial MO concentrations of $25,50,75$, and $100 \mathrm{mg} / \mathrm{L}$.

Figure 8 shows the effect of irradiation time on the photocatalytic degradation of MO at concentrations of $25,50,75$, and $100 \mathrm{mg} / \mathrm{L}$, the catalyst dose of $0.05 \mathrm{~g} / \mathrm{L}$, as well as $\mathrm{pH}$ of 4 , under UV light. The results showed MO removal increases along with irradiation time; however, at 160 minutes of irradiation, there was no increase in the amount of degraded MO. Furthermore, the highest MO removal was obtained at a concentration of $25 \mathrm{mg} / \mathrm{L}(93.46 \%)$. This is because higher concentrations tend to block light from reaching the catalyst, consequently, reducing the rate of removal.

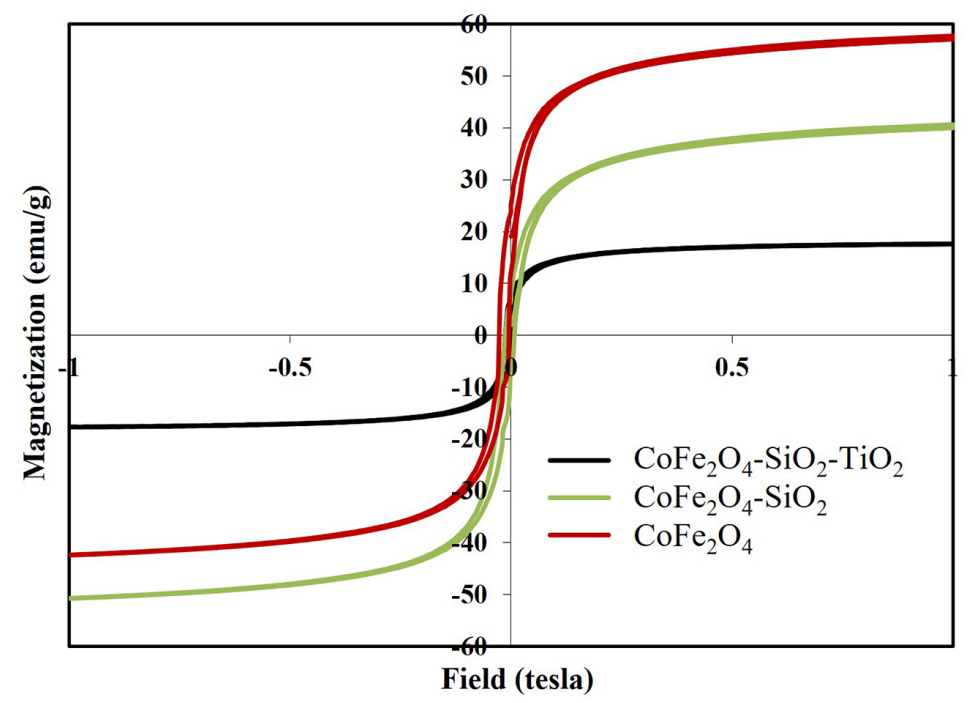

Figure 4. Saturation magnetization curves of (a) $\mathrm{CoFe}_{2} \mathrm{O}_{4}$, (b) $\mathrm{CoFe}_{2} \mathrm{O}_{4}-\mathrm{SiO}_{2}$ and (c) $\mathrm{CoFe}_{2} \mathrm{O}_{4}-\mathrm{SiO}_{2}-\mathrm{TiO}_{2}$ 
a)

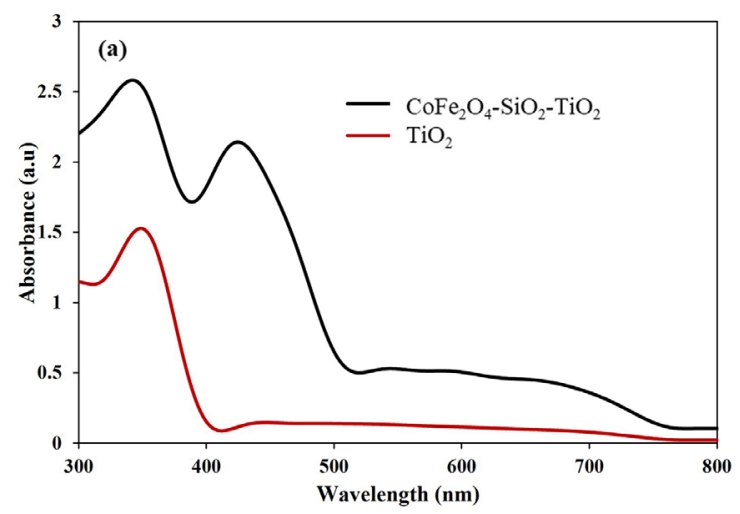

b)

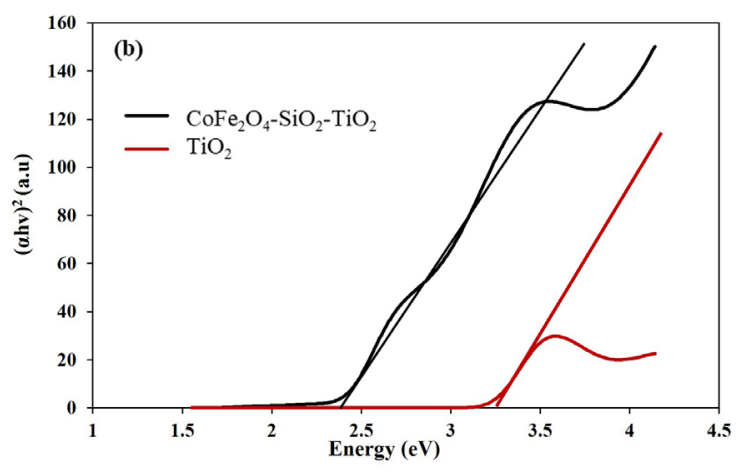

Figure 5. (a) UV-DRS spectra of $\mathrm{CoFe}_{2} \mathrm{O}_{4}-\mathrm{SiO}_{2}-\mathrm{TiO}_{2}$ and pure $\mathrm{TiO}_{2}$ and (b) band gab of $\mathrm{CoFe}_{2} \mathrm{O}_{4}-\mathrm{SiO}_{2}-\mathrm{TiO}_{2}$ and pure $\mathrm{TiO}_{2}$

The Langmuir Hinshelwood equation model is generally used to describe the kinetics of heterogeneous photocatalytic degradation. This equation is further simplified to pseudo-firstorder kinetics to obtain the following equation (Eq. 2) [Amulya et al., 2020]:

$$
\ln \left(\frac{C}{C_{0}}\right)=-k t
$$

where: $C_{o}$ and $C$ are the initial concentration and the concentration after the photocatalytic degradation process, respectively, at a time $(t)$.

Figure 8 shows the photocatalytic degradation kinetics of $\mathrm{MO}$ at concentrations of 25, 50, 75, and $100 \mathrm{mg} / \mathrm{L}$, catalyst dose of $0.05 \mathrm{~g} / \mathrm{L}$, as well as $\mathrm{pH}$ of 4 , under UV light. The concentrations produced $\mathrm{R}^{2}$ values indicating the photocatalytic degradation has adequate linearity and follows the Langmuir-Hinshelwood model expressed in pseudo-first-order. Similar results were reported for the photocatalytic degradation of the Methylene blue dye using $\mathrm{TiO}_{2}-\mathrm{Fe}_{3} \mathrm{O}_{4}$-bentonite [Chen et al., 2015], as well as the photocatalytic degradation of $\mathrm{Cr}(\mathrm{VI})$ using $\mathrm{NiFe}_{2} \mathrm{O}_{4}-\mathrm{SiO}_{2}-\mathrm{TiO}_{2}$ [Ojemaye et al., 2017]. Table 3 shows the kinetics parameters of $\mathrm{MO}$ photocatalytic degradation where the $t_{1 / 2}$ value is calculated using $0.693 / k$.

\section{Reusability of the photocatalyst}

The regenerability and reusability of catalysts are highly significant in industrial contexts, because these properties are related to cost, pilotscale remediation systems, and environmental safety [Moosavi et al., 2020T; Ajabshir and Niasari, 2020]. Reusing catalysts reduces the

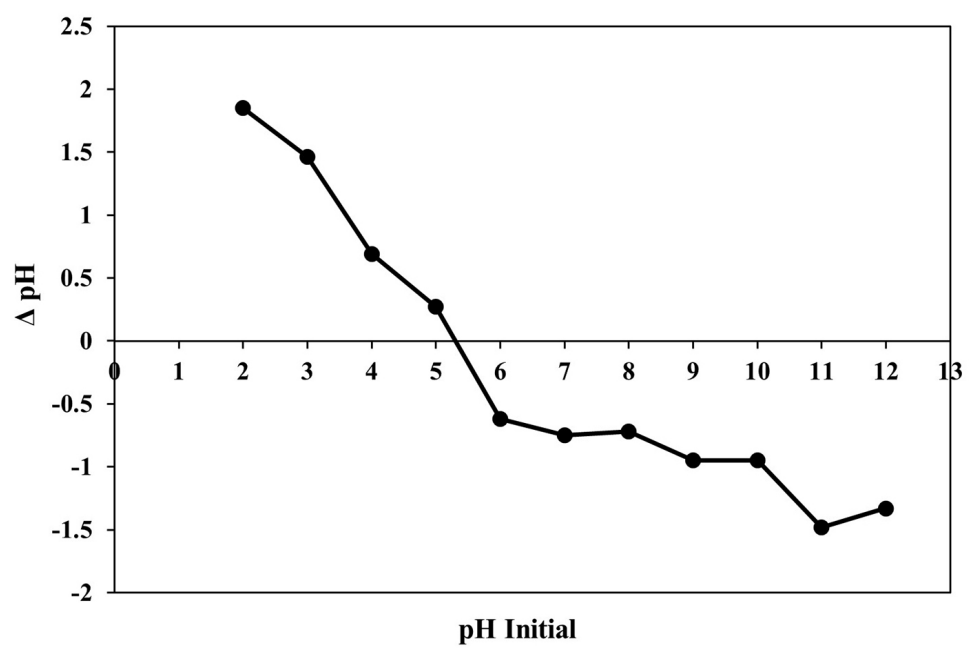

Figure 6. $\mathrm{pHpzc}$ of $\mathrm{CoFe}_{2} \mathrm{O}_{4}-\mathrm{SiO}_{2}-\mathrm{TiO}_{2}$ 


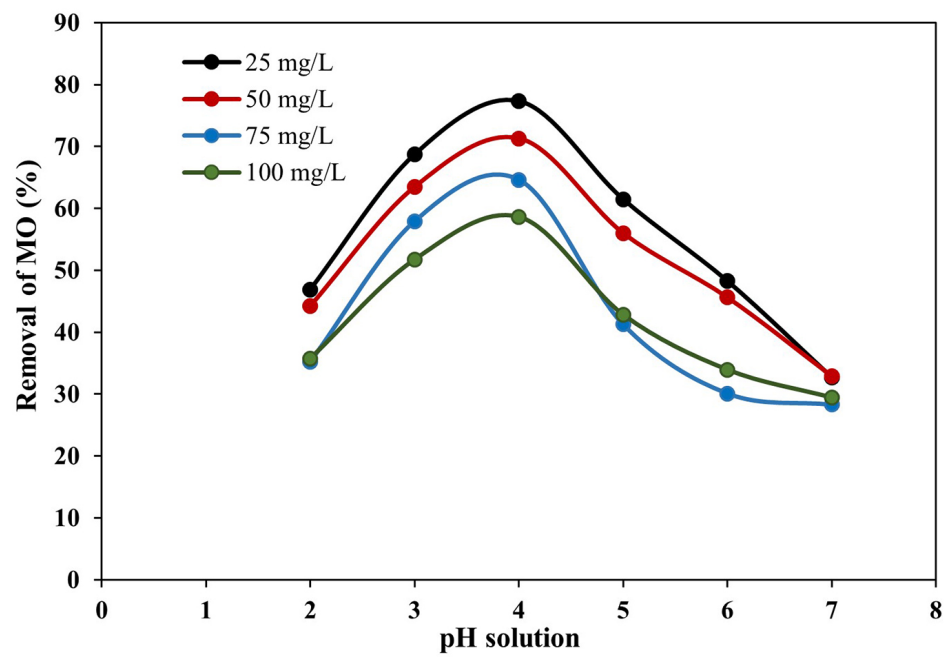

Figure 7. Effect of solution $\mathrm{pH}$ on removal MO

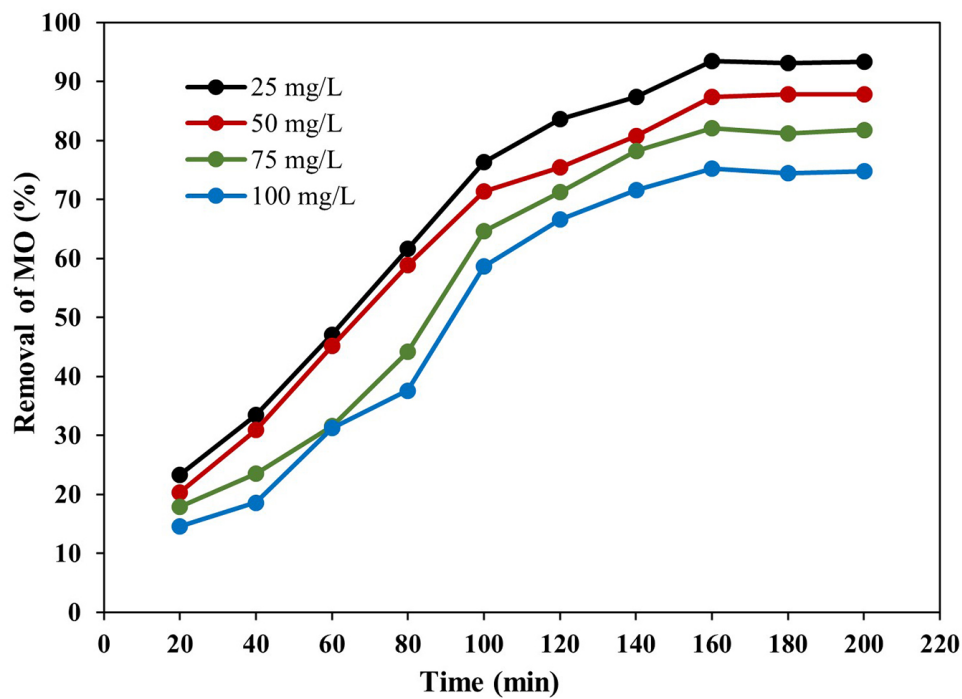

Figure 8. Effect of irradiation time on removal MO

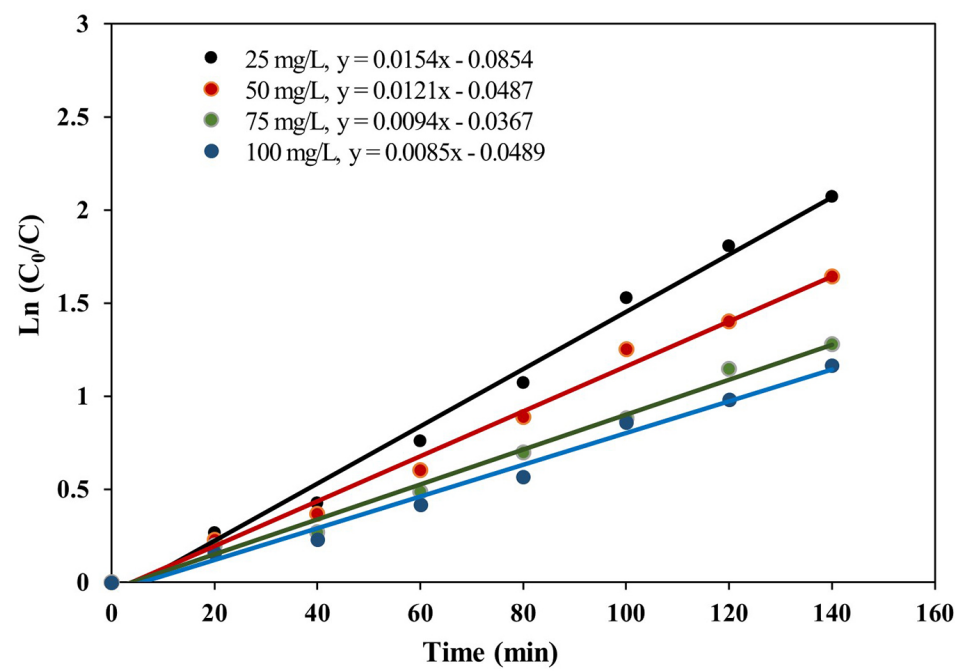

Figure 9. Kinetic photocatalytic degradation of $\mathrm{MO}$ by $\mathrm{CoFe}_{2} \mathrm{O}_{4}-\mathrm{SiO}_{2}-\mathrm{TiO}_{2}$ 
Table 3. Kinetic parameter of photocatalytic degradation $\mathrm{MO}$

\begin{tabular}{|c|c|c|c|}
\hline $\mathrm{MO}(\mathrm{mg} / \mathrm{L})$ & $\mathrm{R}^{2}$ & $\mathrm{k}\left(\mathrm{min}^{-1}\right)$ & $\mathrm{t}_{1 / 2}(\mathrm{~min})$ \\
\hline 25 & 0.9902 & 0.0154 & 45.0 \\
\hline 50 & 0.9909 & 0.0121 & 57.3 \\
\hline 75 & 0.9907 & 0.0094 & 73.7 \\
\hline 100 & 0.9859 & 0.0085 & 81.5 \\
\hline
\end{tabular}

discharge of secondary pollutants into the environment. Photocatalytic degradation is carried out using a $\mathrm{MO}$ concentration of $25 \mathrm{mg} / \mathrm{L}$, a $\mathrm{pH}$ of 4 , a catalyst dose of $0.05 \mathrm{~g} / \mathrm{L}$, as well as an irradiation time of 160 minutes. According to Figure 10, the catalyst effectiveness reduced by $3.74 \%$, from $93.46 \%$ to $89.96 \%$, after 5 cycles. Moosavi et al. [2020] reported similar results in the effectiveness of $\mathrm{Fe}_{3} \mathrm{O}_{4} / \mathrm{AC} / \mathrm{TiO}_{2}$ in photocatalytic degradation which reduced from approximately $98 \%$ to about $93 \%$ after 7 cycles. This study obtained better results, compared to MO degradation using $\mathrm{Ti}_{2}-\mathrm{Fe}_{3} \mathrm{O}_{4}$-bentonite, where the catalyst effectiveness decreased by approximately $20 \%$ after 6 cycles. Furthermore, the reduction in the catalyst effectiveness is possibly due to the loss of material during the photocatalytic degradation process (separation, washing, and drying), as well as the occurrence of catalyst aggregation.

A total organic carbon (TOC) analysis was also performed to determine the amount of organic matter or the level of mineralization. According to Pourzad et al., [2020], the level of mineralization is usually not fully achieved. The TOC efficiency on photocatalytic degradation of methylene blue dye using $\mathrm{Ag}_{2} \mathrm{O}-\mathrm{NiO} / \mathrm{CuFe}_{2} \mathrm{O}_{4}$ catalyst is $78.64 \%$ [Liu et al., 2020], while the
TOC efficiency of paraquat using $\mathrm{N}$-doped $\mathrm{TiO}_{2}$ $\mathrm{SiO}_{2}-\mathrm{Fe}_{3} \mathrm{O}_{4}$ is $84.71 \%$ [Pourzad et al., 2020]. In this study, the efficiency of TOC removal for photocatalytic degradation of MO under optimal conditions with a concentration of $25 \mathrm{mg} / \mathrm{L}$, catalyst dose of $0.05 \mathrm{~g} / \mathrm{L}$, solution $\mathrm{pH}$ of 4 , and irradiation time of 160 minutes is $82.68 \%$. This result indicates a successful dye decomposition process.

\section{CONCLUSIONS}

A core-shell-shell composite in the form of $\mathrm{CoFe}_{2} \mathrm{O}_{4}-\mathrm{SiO}_{2}-\mathrm{TiO}_{2}$ was successfully synthesized and effectively used for photocatalytic degradation of methyl orange dye under UV light irradiation. On the basis of the XRD analysis, $\mathrm{CoFe}_{2} \mathrm{O}_{4}$ was discovered to possess a cubic spinel structure and $\mathrm{TiO}_{2}$ was in the anatase phase. In addition, the FTIR and SEM-EDS analyses confirmed the presence of $\mathrm{SiO}_{2}$ and $\mathrm{TiO}_{2}$ shells. The $\mathrm{CoFe}_{2} \mathrm{O}_{4}-\mathrm{SiO}_{2}-$ $\mathrm{TiO}_{2}$ composite possessed magnetic properties with a saturation magnetization of $47 \mathrm{emu} / \mathrm{g}$, as well as a bandgap of $2.4 \mathrm{eV}$. Furthermore, the removal efficiency of $\mathrm{MO}$ using $\mathrm{CoFe}_{2} \mathrm{O}_{4}-\mathrm{SiO}_{2}-\mathrm{TiO}_{2}$ was discovered to be $93.46 \%$ with a $\mathrm{MO}$ concentration of $25 \mathrm{mg} / \mathrm{L}$, solution $\mathrm{pH}$ of 4 , catalyst dose of $0.05 \mathrm{~g} / \mathrm{L}$, and irradiation time of 160 minutes under UV light irradiation. In addition, the photocatalytic degradation followed the Langmuir-Hinshelwood model expressed in pseudo-first-order. These results show that $\mathrm{CoFe}_{2} \mathrm{O}_{4}-\mathrm{SiO}_{2}-\mathrm{TiO}_{2}$ has the potential for use in wastewater treatment, especially for organic pollutant removal. The catalyst effectiveness decreased by only $3.74 \%$ after 5 cycles of photocatalytic degradation.

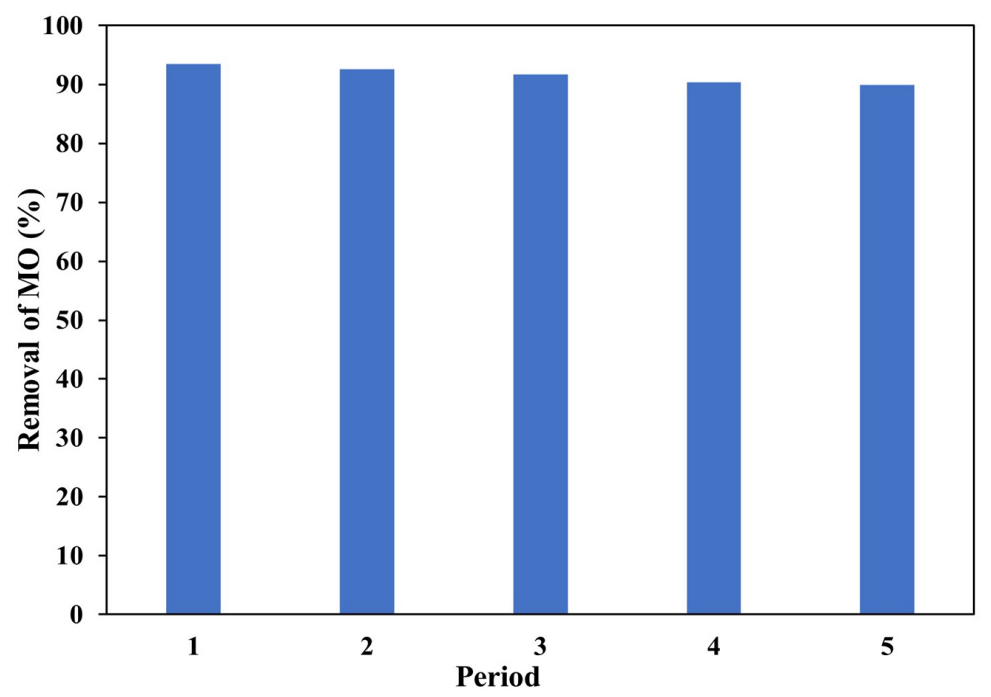

Figure 10. Reusability of the $\mathrm{CoFe}_{2} \mathrm{O}_{4}-\mathrm{SiO}_{2}-\mathrm{TiO}_{2}$ photocatalyst 


\section{Acknowledgement}

The authors are grateful to the Kemendikbud Ristek for the provision of financial aid towards this study, under the Penelitian Dasar Unggulan Perguruan Tinggi scheme with Contract No. 0166.15/UN9/SB3.LP2M.Pt/2021.

\section{REFERENCES}

1. Ahmad M., Ahmed E., Hong Z.L., Ahmed W., Elhissi A., Khalid N.R. 2014. Photocatalytic, sonocatalytic and sonophotocatalytic degradation of Rhodamine B using $\mathrm{ZnO} / \mathrm{CNTs}$. Ultrasonics Sonochemsitry, 21(2), 761-773.

2. Ajabshir S.Z., Niasari M.S. 2019. Preparation of magnetically retrievable $\mathrm{CoFe}_{2} \mathrm{O}_{4}-\mathrm{SiO}_{2}-\mathrm{Dy}_{2} \mathrm{Ce}_{2} \mathrm{O}_{7}$ nanocomposites as novel photocatalyst for higly efficient degrdation of organic contaminants. Composites Part B: Engineering, 174, 1-9.

3. Ajmal A., Majeed I., Malik R.N., Idriss H., Nadeem M.A. 2014. Principles and mechanisms of photocatalytic dye degradation on $\mathrm{TiO}_{2}$ based photocatalytic a comparative overview. RSC Advances, 4, 37003-37026.

4. Alghamdi A.A., Al-Odayni A.B., Saeed W.S., Almutairi MS., Alharthi, F.A.A, Aouak T., Al-Kahtani AA. 2019. Adsorption of azo dye Methyl Orange from aquaeous solutions using alkali-activated polypyrrole-based graphene oxide. Molecules, 24, 1-17.

5. Amulya M.A.S., Nagaswarupa H.P., Kumar M.R.A., Ravikumar C.R., Prashantha S.C., Kusuma KB. 2020. Sonochemical synthesis of $\mathrm{NiFe}_{2} \mathrm{O}_{4}$ nanoparticles: Characterization and their photocatalytic and electrochemical applications. Applied Surface Sciences Advances, 1, 1-10.

6. Awazu K., Fujimahi M., Rockstuhi C., Tominaga J., Murakami H., Ohki Y. 2008. A plasmonic photocatalyst consisting of silver nanoparticles embedded in titanium dioxide. Journal of the American Chemical Society, 130(5), 1676-1680.

7. Behzadi S., Nonahal B., Royaee S.J., Asadi A.A. 2020. $\mathrm{TiO}_{2}-\mathrm{SiO}_{2}-\mathrm{Fe}_{3} \mathrm{O}_{4}$ magnetic nanoparticles synthesis and appication in methyl orange photocatalytic removal. Water Science \& Technology, 82 (11), 2432-2445.

8. Chan T., Zheng Y., Lin J.M., Chen G. 2008. Study on the photocatalytic degradation of Methyl Orange in water using $\mathrm{Ag}-\mathrm{ZnO}$ as catalyst by Liquid Chromatograpgy Electrospray Ionization Ion-Trap Mass Spectrometry. Journal of the American Society for Mass Spectrometry, 19, 997-1003.

9. Chen W., Xiao H., Xu H., Ding T., Gu Y. 2015. Photodegrdation of Methylene Blue by $\mathrm{TiO}_{2}-\mathrm{Fe}_{3} \mathrm{O}_{4}$ Bentonite magnetic nanocomposite. International Journal of Photoenergy, 2015, 1-7.
10. Cheng J., Ma R., Li M., Wu J., Liu F., Zhang X. 2012. Anatase nanocrystals coating on silica-coated magnetite: role of polyacrylic acid treatment and its photocatalytic properties. Chemical Engineering Journal, 210(7), 80-86.

11. Djellabi, R., Yang, B., Wang, Y., Cui, X., Zhao, X. 2019. Carbonaceous biomass-titania composites with $\mathrm{Ti}-\mathrm{O}-\mathrm{C}$ bonding bridge for efficient photocatalytic reduction of $\mathrm{Cr}(\mathrm{VI})$ under narrow visible light. Chemical Engineering Journal, 366, 172-180.

12. El-Shobaky G., Turky A., Mostafa N., Mohamed S. 2010. Effect of preparation conditions on physicochemical, surface and catalytic properties of cobalt ferrite prepared by coprecipitation. Journal of Alloys and Compounds, 493, 415-422.

13. Fu C., Liu X., Wang Y., Li L., Zhang Z. 2019. Preparation and characterization of $\mathrm{Fe}_{3} \mathrm{O}_{4}-\mathrm{SiO}_{2}-\mathrm{TiO}_{2}-\mathrm{Co}-$ rGO magnetic visible light photocatalyst for water treatment. RSC Advances, 9, 20256-20265.

14. Gebrezgiabher M., Gebreslassie G., Gebretsadik T., Yeabyo G., Elemo F., Bayeh Y., Thomas M., Linert W. 2019. AC-Doped $\mathrm{TiO}_{2}-\mathrm{Fe}_{3} \mathrm{O}_{4}$ Nanocomposite for Photocatalytic Dye 2018. Degradation under Natural Sunlight Irradiation. Journal of Composite Science, 3(3), 1-11.

15. Ge J., Zhang Y., Heo Y.J., Park S.J. 2019. Advanced design and synthesis of composite photocatalysts for the remediation of wastewater: a review. Catalysts, 9(2), 1-32.

16. Habila M.A., Al-Othman Z.A., El-Toni A.M., Labis J.P., Soylak M. Synthesis and application of $\mathrm{Fe}_{3} \mathrm{O}_{4}$ $\mathrm{SiO}_{2}-\mathrm{TiO}_{2}$ for photocatalitic decomposition of organic matrix simultaneously with magnetic solid phase extraction of heavy metals prior to ICP-MS analysis. Talanta, 154, 539-547.

17. Huang J.H., Huang K.L., Liu S.Q., Wang A.T., Yan C. 2008. Adsorption of Rhodamine B nad Methyl Orange on a hypercrosslinked polymer adsorbent in aqueous solution. Colloids and Surfaces A: Physicochemical and Engineering Aspects, 330(1), 55-61.

18. Houshiar M., Zebhi F., Razi Z.J., Alidoust A., Askari Z. 2014. Synthesis of cobalt ferrite $\left(\mathrm{CoFe}_{2} \mathrm{O}_{4}\right)$ nanoparticles using combustion, coprecipitation, and precipitation methods: A comparison study of size, structural, and magnetic properties. Journal of Magnetism and Magnetic Materials, 371, 43-48.

19. Jurek A.Z., Bielan Z., Dudziak S., Wolak I., Sobczak T., Klimczuk T., Nowaczyk G., Hupka J. 2017. Design and application of magnetic photocatalysts for water treatment. The effect of particle charge on surface functionality. Catalysts, 360(7), 1-18.

20. Jorfi S., Kakavandi B., Motlagh H.R., Jaafarzadeh N. 2017. A novel combination of oxidative degradation for benzotriazole removal using $\mathrm{TiO}_{2}$ loaded on $\mathrm{Fe}^{\mathrm{II}} \mathrm{Fe}_{2}{ }_{2}{ }^{\mathrm{III}} \mathrm{O}_{4}-\mathrm{C}$ as an efficient activator of peroxymonosulfate. Applied Catalysis B: Environmental, 219, 216-230. 
21. Konstantinou I.K., Albanis T.A. 2004. $\mathrm{TiO}_{2}$-assisted photocatalytic degradation of azo dyes in aqueous solution: Kinetic and mechanistic investigations. Applied Catalysis B: Environmental, 49, 1-14.

22. Koohestani H., Sadrnezhaad S.K. 2016. Photocatalytic degradation of Methyl Orange and Cyanide by Using $\mathrm{TiO}_{2}-\mathrm{CuO}$ composite. Desalination and Water Treatment, 2016, 1-10.

23. Lee S.A., Choo K.H., Lee CH., Lee H.I., Hyeon T., Choi W., Kwon H.H. 2001. Use of ultrafiltration membranes for the separation of $\mathrm{TiO}_{2}$ photocatalysts in drinking water treatment. Industrial \& Engineering Chemistry Research, 40(7), 1712-1719.

24. Liu L., Hu N., An Y., Du X., Zhang X., Li Y., Zeng Y., Cui Z. 2020. $\mathrm{Ag}_{2} \mathrm{O}$ and $\mathrm{NiO}$ decorated $\mathrm{CuFe}_{2} \mathrm{O}_{4}$ with enhaced photocatalytic performance to improve the degradation efficiency of Methylene Blue. Materials, 13, 1-12.

25. Mercyrani B., Maya R.H., Lopez M.S., Th-Th C., Velumani S. 2017. Photocatalytic degrAdation of Orange $\mathrm{G}$ using $\mathrm{TiO}_{2}-\mathrm{Fe}_{3} \mathrm{O}_{4}$ nanocomposite. Journal of Materials Science: Materials in Electronics, 29, 15436-15444.

26. Mishra P., Patnaik S., Parida K. 2019. An overview of recent progresses on noble metal modified magnetic $\mathrm{Fe}_{3} \mathrm{O}_{4}$ for photocatalytic pollutant degradation and $\mathrm{H}_{2}$ evolution. Catalysis Science \& Technology, 9, 916-941.

27. Moosavi S., Li R.Y.M., Lai C.W., Yusof Y., Gan S., Akbarzadeh O., Chowhury Z.Z., Yue X.G, Johan M.R. 2020. Methylene blue dye photocatalytic degradation over synthesises $\mathrm{Fe}_{3} \mathrm{O}_{4}-\mathrm{AC}-\mathrm{TiO}_{2}$ nanocatalyst: Degrdation and reusability Studies. Nanomaterials, 10(12), 1-15.

28. Mortazavi D.S., Salavati D.M., Abbasi N.O.A.A. 2017. Fabrication and characterization of $\mathrm{Fe}_{3} \mathrm{O}_{4}$ $\mathrm{SiO}_{2}-\mathrm{TiO}_{2}-\mathrm{Ho}$ nanostructures as a novel and highly efficient photocatalyst for degradation of organic pollution. Journal of Energy Chemistry, 26(1), $17-23$.

29. Mrotek E., Dudziak S., Malinowska I., Pelczarski D., Ryzynska Z., Juruk A.Z. 2020. Improved degradation of etodolac in the presence of core-shell $\mathrm{ZnFe}_{2} \mathrm{O}_{4}-\mathrm{SiO}_{2}-\mathrm{TiO}_{2}$ magnetic photocalyst. Science of The Total Environment, 724, 1-12.

30. Nair P.G., Vijayakumar S., Lisluke T., Mathew M.S.P, Aravindakumar CT. 2014. Degradation of dyestuff pollutant Sudan I using advanced oxidation process. Journal of water Resource and Protection, 6(14), 1276-1283.

31. Ojemaye, M.O., Okoh O.O., Okoh A.I. 2017. Performance of $\mathrm{NiFe}_{2} \mathrm{O}_{4}-\mathrm{SiO}_{2}-\mathrm{TiO}_{2}$ magnetic photocatalyst for the effective photocatalytic reduction of $\mathrm{Cr}(\mathrm{VI})$ in aquation solutions. Journal of Nanomaterials, 2017, 1-11.

32. Pastravanu C.C., Ignat M., Popovici E., Harabagiu V. 2014. $\mathrm{TiO}_{2}$-coated mesoporous carbon:
Conventional vs. microwave-annealing process. Journal of Hazardous Materials, 278, 382-390.

33. Pourzad A., Sobhi H.R., Behbahani M., Esrafili A., Kalantary R.R., Kermani M. 2020. Efficient visible light-induced photocatalytic removal of paraquat using $\mathrm{N}$-doped $\mathrm{TiO}_{2}-\mathrm{SiO}_{2}-\mathrm{Fe}_{3} \mathrm{O}_{4}$ nanocomposite. Journal of Molecular Liquids, 299, 1-7.

34. Rashid J., Barakat M.A., Ruzmanova Y., Chianese A. 2015. $\mathrm{Fe}_{3} \mathrm{O} 4-\mathrm{SiO}_{2}-\mathrm{TiO}_{2}$ nanoparticles for photocatalytic degradation of 2-chlorophenol in simulated wastewater. Environmental Science and Pollution Research, 22, 3149-3157.

35. Rajput J.K., Kaur G. 2014. Synthesis and applications of $\mathrm{CoFe}_{2} \mathrm{O}_{4}$ nanoparticles for multicomponent reaction. Catalysis Science \& Technology, 4, 142-151.

36. Shojaie A., Fattahi M., Jorfi S., Ghasemi B. 2018. Synthesis and evaluations of $\mathrm{Fe}_{3} \mathrm{O}_{4}-\mathrm{TiO}_{2}-\mathrm{Ag}$ nanocomposites for photocatalytic degradation of 4-chlorophenol (4-CP): effect of Ag and Fe compositions. International Journal of Industrial Chemistry, 9, 141-151.

37. Stefan M., Leostean C., Pana O., Toloman D., Popa A., Perhaita I., Senila M., Marincas O., Tudoran LB. 2016. Magnetic recoverable $\mathrm{Fe}_{3} \mathrm{O}_{4}-\mathrm{TiO}_{2}$ : Eu composite nanoparticles with enhanced photocatalytic activity. Applied Surface Science, 390, 248-259.

38. Subramonian W., Wu T.Y., Chai S.P. 2017. Photocatalytic degradation of industrial pulp and paper mill effluent using synthesized magnetic $\mathrm{Fe}_{2} \mathrm{O}_{3}$ $\mathrm{TiO}_{2}$ : Treatment efficiency and characterizations of reused photocatalyst. Journal of Environmental management, 187, 298-310.

39. Suzuki H., Araki S., Yamamoto H., 2015. Evaluation of advanced oxidation processes (AOP) using $\mathrm{O}_{3}$, $\mathrm{UV}$, and $\mathrm{TiO}_{2}$ for the degradation of phenol in water. Journal of Water Process Engineering, 7, 54-60.

40. Sonu, Duta V., Sharma S., Raizada P., Bandegharaei A.H., Gupta V.K., Singh P. 2019. Review on augmentation in photocatalytic activity of $\mathrm{CoFe}_{2} \mathrm{O}_{4}$ via heterojunction formation for photocatalysis of organic pollutants in water. Journal of Saudi Chemical Society, 23, 1119-1136.

41. Takdastan A., Kakavandi B., Azizi M., Golshan M. 2018. Efficient activation of peroxymonosulfate by using ferroferric oxide supported on carbon/UV/US system: A new approach into catalytic degradation of bisphenol A. Chemical Engineering Journal, 331, 729-743.

42. Trabelsi H., Atheba G.P., Hentati O, Meriette Y.D, Robert D, Drogui P., Ksibi M. 2016. Solar photocatalytic decolorization and degradation of Methyl Orange using supported $\mathrm{TiO}_{2}$. Journal of Advanced Oxidation Technologies, 19 (1), 79-84.

43. Wysocka I., Kowalska E., Trzcinski K., Lapinski M., Nowaczyk G., Jurek A.Z. 2018. UV-vis-induced degradation of phenol over magnetic photocatalysts modified with $\mathrm{Pt}, \mathrm{Pd}, \mathrm{Cu}$ and $\mathrm{Au}$ nanoparticles. Nanomaterials, 8(1), 1-20. 